\title{
Thyroid hormones in genetically lean or fat chickens : effects of age and triiodothyronine supplementation
}

\author{
B. LECLERCQ, G. GUY, Florence RUDEAUX
}

Station de Recherches Avicoles,

I.N.R.A.. Nouzilly, 37380 Monnaie, France.

Summary. Thyroid hormones were measured in plasma of genetically lean (LL) or fat (FL) chickens at different ages. No differences were observed at hatching or at adult age. More triiodothyronine (T3) and less thyroxine (T4) were found in the plasma of LL than in $\mathrm{FL}$ at the fed state during the growth period. This difference disappeared as the birds approached sexual maturity. Dietary supplementation by T3 increased the plasma concentration of T3 at the fed state. It did not influence growth rate, feed efficiency and body temperature. T3 supplementation tended to decrease abdominal fat proportion. It is suggested that the difference in plasma T3 would account for only a small proportion of the between-genotype differences in fattening.

\section{Introduction.}

There is evidence that altered thyroid hormone metabolism may play a role in the development of obesity in mammals (Bray and York, 1971 ; York et al., 1972 ; Durbin-Naltchayan et al., 1983). This may be explained mostly by a decrease in the deiodination of thyroxine (T4) to triiodothyronine (T3) (Kaplan and Young, 1987; Hillgartner and Romsos, 1985 ; Young et al., 1984). An obese line which exhibits auto-immune thyroiditis has been described in chickens (Cole, 1966). Moreover Stewart and Washburn (1983) found a negative correlation between plasma T3 and carcass fat.

We recently observed that our chicken lines selected for leanness or fatness showed significant differences in thyroid hormones, the T3 concentration of LL being superior to that of $F L$ and $T 4$ concentration of LL being inferior to that of FL (Saadoun et al., 1988). This aspect has been further investigated to determine : 1) the effect of age and 2) if this difference in thyroid hormones could account for the difference in fattening. In the present study, we increased plasma T3 concentration by giving diets with different levels of T3 since added T3 may decrease the fat content of birds (Tixier et al., 1986 ; Decuypere et al., 1987) as in mammals (Hollingworth et al., 1970).

\section{Materials.}

Two experiments were undertaken. In experiment 1 blood samples were collected during a longitudinal study of lipid repartition in the carcass according 
to age (Leclercq et al., 1988). Birds of fat (FL) and lean (LL) lines belonging to the F10 (twenty replicates per line) were sampled at hatching and at 9 weeks and 16 weeks of age. Except at hatching, birds were sampled at the fed state and only males were studied. Raising conditions have been described elsewhere (Leclercq et al., 1988). Males and females were also sampled at 36 weeks of age. They were housed in individual cages and blood was collected at the fed state.

Experiment 2 was performed on males of both lines between 26 and 54 days of age. The birds were raised from hatching to 26 days of age in floor pens and then placed in individual cages. The room temperature was maintained at a constant level of $25^{\circ} \mathrm{C}$. Daylength was equal to 16 hours. Birds in each line were distributed in 3 experimental groups with 12 birds per treatment. Ten birds from each line of another group raised simultaneously were killed at the age of 26 days to determine the abdominal fat. Each experimental lot received one of the 3 experimental diets differing in T3 supplementation $(0,0.1$ or $0.2 \mathrm{ppm})$. T3 supplementation was chosen in order to increase the plasma concentration of T3 in FL just below or above the level of unsupplemented LL chickens at the fed state. T3 was added to a classical grower containing $450 \mathrm{~g}$ of corn, $270 \mathrm{~g}$ of wheat, $180 \mathrm{~g}$ soybean meal, $57 \mathrm{~g}$ of meat meal, $20 \mathrm{~g}$ of animal fat, $0.67 \mathrm{~g}$ of methionine, minerals and vitamins per $\mathrm{kg}$. The T3 was pulverized during feed mixing in a vertical mixer and was used as an aqueous solution containing 0,20 , $40 \mathrm{ppm}$ of T3 (Sigma). Five hundred grams of solution were added to $99.5 \mathrm{~kg}$ of feed. Each experimental diet was then pelleted ( $2 \mathrm{~mm}$ diameter). Individual feed consumptions and weight gains were recorded. Blood samples were collected at 42 days of age at the fed or starved (18 h starvation) state. Internal temperature was measured at the fed state at 50 days of age. At the end of the experimental period the birds were starved for $18 \mathrm{~h}$ and killed by injecting sodium pentobarbital. Abdominal fat was then dissected and weighed.

Thyroid hormone concentrations were measured as described previously (Saadoun et al., 1988) using commercial kits either from SABP Hoechst Behring (92504 Rueil-Malmaison, France) or ORIS (91190 Gif-sur-Yvette, France). The data were analysed according analysis of variance using line and T3 supplementation as the main variables.

\section{Results.}

The plasma thyroid hormone concentrations recorded in experiment 1 are shown in table 1. No difference was found either at hatching or at 16 and 34 weeks of age. At 9 weeks of age T3 concentration was significantly higher in LL than in FL. On the contrary T4 concentrations were not significantly different in $L L$ and in FL. Similar trends could still be observed at 16 weeks of age, but differences were not significant.

Growth performances observed during experiment 2 are given in table 2 . As expected, highly significant effects $(P<0.01)$ were found between genotypes for abdominal fat and feed efficiency. T3 supplementation slightly decreased abdominal fat content $(P<0.05)$ but did not significantly modify growth rate, 
TABLE 1

Plasma triiodothyronine (T3) and thyroxine (T4) concentrations in genetically lean (LL) or fat (FL) chickens (mean \pm standard error).

\begin{tabular}{|c|c|c|c|c|}
\hline & \multicolumn{2}{|c|}{$\begin{array}{c}\mathrm{T} 3 \\
(\mathrm{ng} / \mathrm{ml})\end{array}$} & \multicolumn{2}{|c|}{$\begin{array}{c}\mathrm{T} 4 \\
(\mathrm{ng} / \mathrm{ml})\end{array}$} \\
\hline & FL & LL & $\mathrm{FL}$ & LL \\
\hline Hatching (both sexes) & $1.85 \pm 0.16$ & $1.50 \pm 0.14$ & $38.7 \pm 4.45$ & $42.7 \pm 3.54$ \\
\hline 9 weeks (males) & $2.03 \pm 0.08^{*}$ & $2.45 \pm 0.13$ & $59.1 \pm 4.90$ & $53.4 \pm 5.11$ \\
\hline 16 weeks (males) & $1.05 \pm 0.08$ & $1.25 \pm 0.08$ & $43.7 \pm 1.03$ & $38.2 \pm 0.86$ \\
\hline \multicolumn{5}{|l|}{34 weeks } \\
\hline Males & $1.60 \pm 0.24$ & $1.61 \pm 0.22$ & $27.5 \pm 7.08$ & $27.1 \pm 8.14$ \\
\hline Females & $1.32 \pm 0.10$ & $1.40 \pm 0.11$ & $51.3 \pm 1.98$ & $55.9 \pm 3.30$ \\
\hline
\end{tabular}

*: Between-genotype difference significant at the $5 \%$ level. All birds were sampled at fed state except at hatching.

\section{TABLE 2}

Effet of triiodothyronine (T3) supplementation on growth performance and body temperature of genetically lean ( $\mathrm{LL}$ ) or fat $(\mathrm{FL})$ chickens (mean \pm standard error).

\begin{tabular}{|c|c|c|c|}
\hline T3 supplementation & 0 & $0.1 \mathrm{ppm}$ & $0.2 \mathrm{ppm}$ \\
\hline \multicolumn{4}{|l|}{$F L$} \\
\hline \multirow{2}{*}{$\begin{array}{l}\text { Body weight } 54 \mathrm{~d}(\mathrm{~g}) \\
\text { Weight gain } 26-54 \mathrm{~d}(\mathrm{~g}) \\
\text { Feed to gain ratio } 26-54 \mathrm{~d} \\
\text { Body temperature }\left({ }^{\circ} \mathrm{C}\right) \\
\text { Abdominal fat to live weight } \\
(\times 100)\end{array}$} & $\begin{array}{r}1624 \pm \quad 33 \\
1132 \pm \quad 30 \\
2.51 \pm 0.04 \\
41.4 \pm 0.05\end{array}$ & $\begin{array}{r}1589 \pm \quad 66 \\
1102 \pm 59 \\
2.57 \pm 0.06 \\
41.7 \pm 0.11\end{array}$ & $\begin{array}{r}1596 \pm 29 \\
1100 \pm 26 \\
2.51 \pm 0.03 \\
41.5 \pm 0.06\end{array}$ \\
\hline & $4.05 \pm 0.24$ & $3.68 \pm 0.20$ & $3.60 \pm 0.14$ \\
\hline \multicolumn{4}{|l|}{$\angle L$} \\
\hline \multirow{2}{*}{$\begin{array}{l}\text { Body weight } 54 \mathrm{~d}(\mathrm{~g}) \\
\text { Weight gain } 26-54 \mathrm{~d}(\mathrm{~g}) \\
\text { Feed to gain ratio } 26-54 \mathrm{~d} \\
\text { Body temperature }\left({ }^{\circ} \mathrm{C}\right) \\
\text { Abdominal fat to live weight } \\
(\times 100)\end{array}$} & $\begin{array}{r}1608 \pm 39 \\
1127 \pm 34 \\
2.29 \pm 0.03 \\
41.6 \pm 0.05\end{array}$ & $\begin{array}{r}1591 \pm \quad 49 \\
1110 \pm \quad 42 \\
2.31 \pm 0.04 \\
41.7 \pm 0.06\end{array}$ & $\begin{array}{rr}1525 \pm & 32 \\
1045 \pm & 30 \\
2.37 \pm 0.04 \\
41.6 \pm 0.06\end{array}$ \\
\hline & $1.48 \pm 0.12$ & $1.22 \pm 0.15$ & $1.14 \pm 0.05$ \\
\hline Analysis of variance & Line effect & T3 effect & Interaction \\
\hline \multirow{2}{*}{$\begin{array}{l}\text { Body weight } 54 \mathrm{~d} \\
\text { Weight gain } 26-54 \mathrm{~d} \\
\text { Feed to gain ratio } 26-54 \mathrm{~d} \\
\text { Body temperature }\left({ }^{\circ} \mathrm{C}\right) \\
\text { Abdominal fat to live weight } \\
(\times 100)\end{array}$} & $\begin{array}{r}\text { N.S. } \\
\text { N.S. } \\
P<0.01 \\
\text { N.S. }\end{array}$ & $\begin{array}{l}\text { N.S. } \\
\text { N.S. } \\
\text { N.S. } \\
\text { N.S. }\end{array}$ & $\begin{array}{l}\text { N.S. } \\
\text { N.S. } \\
\text { N.S. } \\
\text { N.S. }\end{array}$ \\
\hline & $P<0.01$ & $P<0.05$ & N.S. \\
\hline
\end{tabular}

At 26 days of age mean body weights of $\mathrm{FL}$ and $L L$ chickens were 485 and $469 \mathrm{~g}$ respectively ; mean abdominal fat weights were 10.3 and $3.3 \mathrm{~g}$. 
feed efficiency and body temperature. Concentrations of thyroid hormones are presented in table 3 . Significant differences $(P<0.01)$ were found between lines for both hormones, and for both nutritional states. LL chickens exhibited higher T3 concentrations and lower T4 concentrations than FL chickens. T3 supplementation exerted a significant effect only in fed chickens; it increased plasma T3 concentrations without any significant effect on T4.

TABLE 3

Effect of triiodothyronine (T3) supplementation on plasma concentrations of thyroxine (T4) and triodothyronine $(\mathrm{ng} / \mathrm{ml})$ in genetically lean $(\mathrm{LL})$ or fat $(\mathrm{FL})$ chickens (mean \pm standard error).

\begin{tabular}{lcccc}
\hline T3 supplementation & & 0 & $0.1 \mathrm{ppm}$ & $0.2 \mathrm{ppm}$ \\
\hline FL & & & & \\
Fed state & T3 & $1.91 \pm 0.21$ & $2.37 \pm 0.28$ & $2.85 \pm 0.19$ \\
& T4 & $38.8 \pm 1.79$ & $36.0 \pm 1.86$ & $36.2 \pm 1.03$ \\
Starved state & T3 & $0.83 \pm 0.13$ & $0.91 \pm 0.14$ & $0.82 \pm 0.16$ \\
& T4 & $45.6 \pm 1.43$ & $44.8 \pm 1.50$ & $43.2 \pm 2.00$ \\
LL & & & & \\
Fed state & T3 & $2.67 \pm 0.18$ & $2.80 \pm 0.16$ & $3.31 \pm 0.17$ \\
& T4 & $32.2 \pm 1.30$ & $30.0 \pm 1.30$ & $30.0 \pm 1.14$ \\
Starved state & T3 & $1.19 \pm 0.21$ & $1.20 \pm 0.18$ & $1.25 \pm 0.25$ \\
& T4 & $40.5 \pm 1.54$ & $37.6 \pm 1.55$ & $39.2 \pm 1.26$ \\
Analysis of variance & & Line effect & T3 effect & Interaction \\
Fed state & T3 & $\mathrm{P}<0.01$ & $\mathrm{P}<0.01$ & $\mathrm{~N} . \mathrm{S}$. \\
Starved state & T4 & $\mathrm{P}<0.01$ & $\mathrm{~N} . \mathrm{S}$. & $\mathrm{N} . \mathrm{S}$. \\
& $\mathrm{T} 3$ & $\mathrm{P}<0.01$ & $\mathrm{~N} . \mathrm{S}$. & $\mathrm{N} . \mathrm{S}$. \\
& $\mathrm{T} 4$ & $\mathrm{P}<0.01$ & $\mathrm{~N} . \mathrm{S}$. & $\mathrm{N} . \mathrm{S}$. \\
\hline
\end{tabular}

Blood sampling was performed at 42 days of age.

\section{Discussion.}

The present results confirm our previous observations. FL chickens exhibited higher T4 (significant only in experiment 2) and lower T3 concentrations in plasma during the growth period. This difference did not exist at hatching and disappeared progressively as the birds approached the adult state. The most significant differences were found at 42 days (experiment 2 ) and 9 weeks of age (experiment 1) when metabolic deviations leading to leanness or fatness were maximum (Simon and Leclercq, 1982).

In the present experiment a very low level of T3 supplementation was employed to increase the T3 concentration in FL plasma to the level of control LL chickens and to maintain physiological conditions. This supplementation induced a slight but significant reduction of fattening in both lines. The mechanisms by which T3 acts are probably complex but have not been investigated thoroughly 
at the present time. It is well known that T3 stimulates lipogenesis in vitro (Goodridge and Adelman, 1976). However T3 supplementation systematically reduces fatness in vivo. Interactions with other hormones have been demonstrated. It is well established that T3 supplementation reduces plasma $\mathrm{GH}$ in chickens (Harvey, 1983). Similarly it has been recently found that T3 supplementation (1 ppm) reduces plasma insulin and increases glucagon (Cogburn et al., 1986), suggesting that T3 may act indirectly on lipogenesis and lipolysis by changing pancreatic hormone secretion. Lastly, the increase in the metabolic rate induced by $\mathrm{T} 3$ is well documented in all species.

Thus, despite our ignorance of the mechanisms involved in the " antifattening " effect of T3, we may attempt to estimate the proportion of divergence in fattening between the 2 lines which is due to a difference in circulating T3 levels. Expressed as abdominal fat gain divided by weight gain $(\Delta \mathrm{AF} / \Delta \mathrm{W})$, the regression between changes in fattening were calculated for both genotypes:

$$
\begin{aligned}
& \mathrm{FL}: \Delta \mathrm{AF} / \Delta \mathrm{W}=-0.0068 \mathrm{~T} 3+0.0615 \\
& \mathrm{LL}: \Delta \mathrm{AF} / \Delta \mathrm{W}=-0.0063 \mathrm{~T} 3+0.0341 .
\end{aligned}
$$

The $\triangle A F / \Delta W$ of $F L$ chickens exhibiting the same T3 concentration as $L L$ controls $(2.67 \mathrm{ng} / \mathrm{ml})$ could be calculated. This value was 0.0433 . So increasing the plasma T3 of FL chickens to that of $L L$ controls decreased fatness $(\triangle A F / \triangle W)$ from 0.0485 to 0.0433 , i.e. -0.0052 . As the difference between $F L$ and $L L$ controls was $0.0485-0.0173=0.0312$, we may assume that the difference in plasma T3 could explain $0.0052 / 0.0312$, i.e. about $17 \%$ of the betweengenotype difference.

In the present study, as in a previous one (Touchburn et al., 1981), no differences in body temperature were found between lines. Moreover, T3 supplementation did not influence body temperature. Other investigations on the same lines have led to the conclusion that there are no differences in maintenance of the energy requirement (Leclercq and Saadoun, 1982) or in heat production (McLeod and Geraert, 1988) between these genotypes. The slight decrease in fattening due to T3 supplementation was not able to significantly modify energy metabolism and feed efficiency.

In conc/usion, the differences in thyroid hormones observed during the growth period, although significant, may account for only a small proportion of the difference in fatness. Since genetic control of fatness in these lines is polygenic (Leclercq, 1988) we may assume that some genes act by controlling thyroid hormone metabolism, and thus probably the deiodination of T4 to T3.

Reçu en février 1988.

Accepté en avril 1988.

Résumé. Les hormones thyroïdiennes chez les poulets génétiquement maigres ou gras : effets de l'âge et de la supplémentation en triiodothyronine.

Aucune différence de concentrations plasmatiques d'hormones thyroïdiennes n'existe entre poulets issus de lignées génétiquement maigre ( $L L)$ ou grasse ( $F L$ ) à l'éclosion ou à l'âge adulte. Au contraire, à l'état nourri, le génotype maigre présente des concentrations 
supérieures de triiodothyronine (T3) et inférieures de thyroxine (T4) pendant la période de croissance. Cette différence disparaît à l'approche de la maturité sexuelle. La supplémentation de l'aliment avec de la T3 entraîne une élévation de la T3 circulante à l'état nourri, mais ne modifie ni la vitesse de croissance, ni l'efficacité alimentaire, ni la température corporelle. La T3 entraîne un léger amaigrissement des deux génotypes. On en déduit que la différence de concentration plasmatique de T3 peut expliquer au mieux $17 \%$ de la différence d'engraissement entre les deux lignées.

\section{Références}

BRAY G. E., YORK D. A., 1971. Thyroid function of genetically obese rats. Endocrinology, 88, 1095-1101.

COGBURN L. A., LIOU S. S., MCMURTRY, 1986. Plasma levels of insulin and glucagon in broiler chickens fed thyroid active substances. Poult. Sci., 65, 27A.

COLE R. K., 1966. Hereditary hypothyroidism in the domestic fowl. Genetics, 53, 1021-1033.

DECUYPERE E., BUYSE J., SCANES C. G., HUYBRECHTS L., KUHN E. R., 1987. Effects of hyperor hypo-thyroid status on growth, adiposity and level of growth hormone, somatomedin $\mathrm{C}$ and thyroid metabolism in broiler chickens. Reprod. Nutr. Dévelop., 27, 555-565.

DURBIN-NALTCHAYAN S., BOUHNIK J., MICHEL R., 1983. Thyroid status in the obese syndrome of rats. Horm. Metab. Res., 15, 547-549.

GOODRIDGE A. G., ADELMAN T. G., 1976. Regulation of malic enzyme synthesis by insulin, triiodothyronine and glucagon in liver cells in culture. J. Biol. Chem., 252, 3027-3032.

HARVEY S., 1983. Thyroid hormones inhibit growth hormone secretion in domestic fowl (Gallus domesticus). J. Endocrinol., 96, 329-334.

HILLGARTNER F. B., ROMSOS D. R., 1985. Regulation of iodothyronine $5^{\prime}$-deiodination in lean and obese (ob/ob) mice. Am. J. Physiol., 249, E209-E218.

HOLLINGSWORTH D. R., AMATRUDA T. T., SCHEIG R., 1970. Quantitative and qualitative effects of L-triiodothyronine in massive obesity. Metabolism, 19, 934-945.

KAPLAN M. M., YOUNG J. B., 1987. Abnormal thyroid hormone deiodination in tissues of ob/ob and $\mathrm{db} / \mathrm{db}$ obese mice. Endocrinology, 120, 886-893.

LECLERCQ B., SAADOUN A., 1982. Selecting broilers for low or high abdominal fat : comparison of energy metabolism of the lean and fat lines. Poult. Sci, 61, 1799-1803.

LECLERCO B., 1988. Genetic selection of meat-type chicken for high or low abdominal fat content. In LECLERCO B. and WHITEHEAD C. C., Leanness in domestic birds : genetic, metabolic and hormonal aspects. Butterworth.

LECLERCO B., GUY G., RUDEAUX F., 1988. Growth characteristics and lipid distribution in two lines of chicken selected for low or high abdominal fat. Gén. Sél. Evol. (in press).

McLEOD M., GERAERT P. A., 1988. Energy metabolism in fat and lean lines of chickens. In LECLERCO B., WHITEHEAD C. C., Leanness in domestic birds: genetic, metabolic and hormonal aspects. Butterworth.

SAADOUN A., SIMON J., WILLIAMS J., LECLERCO B., 1988. Levels of insulin, corticosterone, T3, T4 and insulin sensitivity of fat and lean chickens. Diab. Metab. 14, 97-103.

SIMON J., LECLERCO B., 1982. Longitudinal study of adiposity in chickens selected for high or low abdominal fat content : further evidence of a glucose insulin imbalance in the fat line. J. Nutr., 112, $1961-1973$.

STEWART P. A., WASHBURN K. W., 1983. Variation in growth hormone, T3 and lipogenic enzyme activity in broiler strains differing in growth and fatness. Growth, 47, 411-425.

TIXIER M., DECUYPERE E., HUYBRECHTS L., MERAT P., 1986. Effects of dietary T3 on growth, feed efficiency and circulating levels of T3, T4, GH and SM-C in sex-linked dwarf chickens. In LARBIER M., Proc. 7th Eur. Poultry Conf. (Paris).

TOUCHBURN S. P., SIMON J., LECLERCQ B., 1981 . Evidence of a glucose insulin imbalance and effect of dietary protein and energy level in chicken selected for high abdominal fat content. J. Nutr., 111, 325-335. 
YORK D. A., HERSHMAN J. M., UTIGER R. D., BRAY G. A., 1972. Thyrotropin secretion in genetically obese rats. Endocrinology, 90, 67-76.

YOUNG R. A., FANG S. L., PROSKY J., BRAVERMAN L. E., 1984. Hepatic conversion of thyroxine to triiodothyronine in obese and lean Zucker rats. Life Sci., 34, 1783-1790. 